\title{
Identifikasi Pemahaman Sains Mahasiswa PGSD UKSW Tentang Pola Makan Sehari-hari Berbasis Home Science Process Skill
}

\author{
Gamaliel Septian Airlanda \\ gairlanda@gmail.com \\ Pendidikan Guru Sekolah Dasar, FKIP, Universitas Kristen Satya Wacana
}

\author{
The Identification Of Science Comprehension Of PGSD UKSW Students In Daily Consumption \\ Pattern / Diet Based On Home Science Process Skill
}

\begin{abstract}
The science process skill is important for teachers. However, not all of the student teachers have the competency, experience, and passion to science. The students of PGSD UKSW come from many kinds of background of middle schools that makes them have some different experiences in science competencies. The specific identification is needed to compare their science understanding/ comprehension. Their daily menu (diet) is the proper way to identify the students' science understanding, because it is an activity that all people have done. The purpose of this research is to identify the students' science comprehension through daily consumption patterns based on Home Science Process Skill (HSPS), modified from the science process skill steps used at home. HSPS has some advantages, as it makes the student enjoy their science learning and find the basic of knowledge from daily life. The survey methodology was used to find detailed facts about the level of science understanding. The data triangulation were gathered through questionnaires, interviews, and observations, that describe HSPS indicators, consisting of: scrutiny, note down, try out, create, tell (cermati, catat, coba, cipta, cerita). The results showed that $74.07 \%$ of the students encounter difficulty especially in the create phase, in which they have to try and create scientific products. It was also found that the highest difficulty was at the the try out and create phase. Thus, the level of student science understanding is still low. The conclusion is an initial stage of an action research to increase every HSPS indicators achievements.
\end{abstract}

Keywords: Student Science Undestanding, Consumption Pattern, Home Science Process Skill

Received date: 7 Januari 2019

Article Info

Revised date: 9 Januari 2019

Accepted date: 22 Januari 2019

\section{PENDAHULUAN}

Pendidikan modern membutuhkan kemampuan analisis masalah serta menciptakan sebuah solusi. Hal ini sangat diperlukan karena kiblat pendidikan abad 21 mengarah pada pengembangan beberapa kemampuan seperti: higher-order thinking skills, deeper learning outcomes, and complex thinking and communication skills (UNESCO, 2015). Sains menjadi salah satu materi kuliah di pendidikan tinggi yang mampu mengembangkan kemampuan tersebut. Pernyataan ini sejalan dengan hakikat pembelajaran sains yang tidak hanya mentransfer sebuah konsep, namun mengajarkan identifikasi, observasi, berhipotesis, menemukan hingga menyelesaikan sebuah masalah (Rustaman, 2011). Karakteristik ini dapat dilaksanakan dengan baik jika seseorang yang belajar sains mampu memahami dan memiliki rasa cinta terhadap Sains itu sendiri. Di sisi lain, Lembaga Pencetak Tenaga Kependidikan (LPTK) memiliki kewajiban untuk menghasilkan calon guru yang siap menghadapi persaingan abad 21. Sama dengan hasil penelitian Faulkner \& Latham (2016) yang membahas tentang "Kualitas Guru di Abad 21". Penelitian tersebut menyimpulkan bahwa seorang guru harus mampu melampaui zona kenyamanan mereka dalam mengajar, memiliki keingintahuan yang tinggi, literasi yang tinggi, siap terhadap segala jenis perubahan karakter dan terus mencari pengalaman sebagai identitas dari seorang guru masa kini. Tentunya pernyataan ini tidak lepas dari terpenuhinya kualitas proses pendidikan di LPTK termasuk sains.

Pendidikan Guru Sekolah Dasar (PGSD) mewajibkan calon guru memiliki kemampuan yang sesuai dengan Peraturan Menteri Pendidikan Nasional No 16 Tahun 2007 tentang Standar Kualifikasi 
Akademik dan Kompetensi Guru. Peraturan tersebut menyatakan bahwa guru SD harus menguasai konsep: IPA, IPS, PKn, Bahasa Indonesia dan Matematika sekaligus. Tuntutan inilah yang menyebabkan pengetahuan serta keterampilan tentang sains calon guru SD menjadi sangat penting. PGSD FKIP Universitas Kristen Satya Wacana telah memberikan porsi untuk mata kuliah berbasis sains bagi calon guru SD. Terdapat 3 mata kuliah yang disajikan, yaitu: Konsep Dasar IPA SD, Kurikulum dan Pembelajaran IPA SD serta Inovasi Pembelajaran IPA SD. Namun, kenyataan di lapangan menunjukkan bahwa mahasiswa PGSD tidak selalu memiliki latar belakang dan pengalaman tentang IPA saat duduk di jenjang pendidikan menengah. Mereka cenderung berasal dari berbagai latar belakang pendidikan seperti: SMK, SMA program Bahasa, SMA program IPS dan sebagian SMA Program IPA. Oleh karena itu, mahasiswa dengan latar belakang pendidikan menengah bukan IPA cenderung lebih sulit memahami materi dalam matakuliah yang disajikan di tahun pertama. Kesulitan yang dihadapi mahasiswa ini berdampak pada sikap mahasiswa yang tidak peduli dan tidak berusaha memberikan performa terbaiknya. Keadaan ini berpengaruh pada pemahaman sains mahasiswa. Hanya 7 dari 27 siswa di kelas RS16A yang lulus tes awal dalam mata kuliah Konsep Dasar IPA SD. Fakta ini cukup memprihatinkan mengingat materi yang diujikan dalam tes tersebut merupakan soal level sekolah dasar yang harusnya dikuasai oleh calon guru. Untuk mampu mengidentifikasi pemahaman sains mahasiswa PGSD UKSW yang memiliki perbedaan latar belakang pendidikan pada saat sekolah menengah diperlukan tinjauan spesifik yang melandasinya.

Tinjauan spesifik ini diperlukan untuk dapat membandingkan tingkat pemahaman mahasiswa pada level tertentu. Kegiatan dalam kehidupan sehari-hari adalah cara yang tepat untuk membandingkan tingkat pemahaman seseorang. Selaras dengan pernyataan tersebut, hasil penelitian Istijabatun (2013) menyimpulkan bahwa pengetahuan siswa dalam kehidupan sehari-hari berkontribusi positif terhadap pemahaman (kognitif) materi IPA. Mempertegas pendapat di atas, hasil penelitian Asyhari \& Clara (2017) juga menyatakan bahwa pengetahuan konten dan pengetahuan epistemik berbanding lurus dengan penyelidikan ilmiah yang dilakukan oleh peserta didik. Pernyataan ini dapat diterjemahkan bahwa seseorang yang kurang berminat untuk menyelidiki hal-hal ilmiah akan memiliki keterbatasan pengetahuan.

Ilmu Pengetahuan Alam sering dimaknai sebagai sesuatu yang hanya bisa dilihat dan dirasakan oleh indera dalam kegiatan sehari-hari. Namun, lebih dari itu, komponen IPA di luar jangkuan indera penglihatan dan perasa justru merupakan pembangun psikologi manusia itu sendiri. Semakin kita memahami komponen tersebut sama dengan mampu memahami hakikat manusia seutuhnya (Franco et all, 2017). Segala aspek dalam kehidupan sehari-hari pastinya berhubungan erat dengan konsep sains, seperti: makan, minum, mencuci, menjemur pakaian, memasak, menonton televisi, menggunakan handphone dan lainnya. Terkadang konsep ini sering dilupakan karena manusia hanya melakukan rutinitas yang seolah-olah tidak memiliki nilai pengetahuan bagi dirinya. Salah satu aktivitas manusia yang tidak pernah terlewatkan semasa hidup adalah makan. Proses pencernaan yang dilakukan oleh manusia (termasuk mahasiswa) setiap hari sering dianggap sebagai suatu hal yang wajar dan tanpa masalah. Pola makan mahasiswa selalu menjadi sorotan karena mereka sering mengutamakan makanan hanya dengan melihat kuantitas bukan kualitasnya. Kondisi ini dapat diangkat sebagai sebuah pembanding antara pengetahuan sains dengan praktek nyata mahasiswa dalam kehidupan sehari-hari.

Hasil observasi menunjukkan sebagian besar mahasiswa hanya memikirkan tentang kondisi lapar dan kenyang saja. Dari pengalaman dosen yang telah mengampu mata kuliah Konsep Dasar IPA SD selama 3 tahun, mahasiswa selalu mengalami kendala konseptual. Mahasiswa terkadang tidak memahami materi level dasar, seolah-olah sama sekali tidak mengenal materi sains. Keadaan ini membuat pembelajaran berlangsung dengan sangat lambat dan tidak memiliki kesempatan untuk membahas materi di level yang lebih tinggi. Sebagai contoh, mahasiswa masih belum paham tentang konsep organ dan sistem organ, sehingga dosen perlu mengulas kembali sebelum masuk ke materi sistem pencernaan. Kegiatan mengulas kembali membutuhkan waktu yang dapat mengurangi agihan pembelajaran satu semester, selain itu tuntutan materi SD yang harus dikuasi seorang guru justru lebih tinggi dari konsep tersebut. Pemahaman seorang calon guru yang belum cukup, akan menjadi kendala ketika mengajar di lapangan. Keprihatinan ini sangat berarti karena porsi mata kuliah Konsep Dasar IPA SD hanya tersaji satu kali selama empat tahun masa studi mahasiswa S1 PGSD.

Muncul sebuah keraguan tentang akar permasalahan yang dihadapi mahasiswa tentang pemahaman sains. Jika ditinjau dari teori, sains hendaknya dapat dirasakan, dilakukan dan dipelajari 
melalui kegiatan yang dilakukan oleh dirinya sendiri (Atmojo, 2012). Dasar dari kegiatan ilmiah yang dilakukan sehari-hari adalah keterampilan proses sains yang merupakan wawasan atau anutan pengembangan keterampilan-keterampilan intelektual, sosial, dan fisik yang bersumber dari kemampuan-kemampuan mendasar yang pada prinsipnya telah ada dalam diri pebelajar (Dimyati, 2006). Dapat dijelaskan bahwa jika seseorang memiliki keterampilan proses sains yang baik, mereka dapat peka terhadap seluruh aktivitas ilmiah dalam dirinya. Kesenjangan yang terjadi, perlu diberikan sebuah solusi yang tepat. Solusi yang diberikan hendaknya telah melalui tahapan identifikasi yang jelas, hal ini dilakukan untuk menjamin ketepatan pemberian solusi dengan permasalahan yang dihadapi mahasiswa. Penelitian untuk mengidentifikasi permasalahan terkadang tidak dilakukan dan tidak dilaporkan. Hal ini akan mendorong peneliti untuk memaksakan metode penyelesaian masalah secara subyektif.

Identifikasi tentang penggunaan home science process skill dirasa sangat perlu sebagai salah satu solusi dalam mengatasi masalah mahasiswa PGSD UKSW. Home science process skill (HSPS) adalah keterampilan ilmiah yang diterapkan dalam kegiatan di rumah. HSPS adalah sebuah pendekatan baru yang telah dipublikasikan sebelumnya oleh Airlanda (2016) yang menyatakan bahwa proses observasi, menemukan masalah, membuat hipotesis, menemukan kajian pustaka, melakukan percobaan dan menemukan kesimpulan dapat dilakukan dengan kegiatan di rumah. Artikel ini sangat sesuai dengan penerapan HSPS karena pola makan mahasiswa PGSD UKSW merupakan aktivitas di luar tatap muka perkuliahan formal (di rumah). Karakteristik dari pendekatan ini adalah: 1) mengutamakan proses ilmiah yang dikemas dalam 5C (cermati, catat, coba, cipta, cerita), 2) mudah dilakukan dan lebih fleksibel, 3) berbasis kegiatan sehari-hari, 4) dapat dikombinasikan dengan beberapa model pembelajaran, 5) pembelajaran menggunakan seluruh media yang ada di dekatnya. Dengan beberapa karakteristik tersebut, maka bukan suatu hal sulit untuk menciptakan pembelajaran yang menyenangkan. Keunggulan ini sangat sesuai dengan pokok permasalahan di atas. Mahasiswa PGSD UKSW berasal dari berbagai latar belakang pendidikan sekolah menengah yang belum tentu memiliki kesukaan terhadap materi IPA atau sains. Oleh karena itu, pembelajaran sains yang menyenangkan serta berkaitan langsung dengan dirinya sendiri menjadi alternatif cara untuk memupuk rasa cinta sains.

Rumusan masalah penelitian ini adalah: bagaimana hasil identifikasi pemahaman sains mahasiswa PGSD UKSW melalui pola makan sehari-hari berbasis home science process skill? Tujuan dari penelitian ini adalah untuk mengidentifikasi pemahaman sains mahasiswa PGSD UKSW melalui pola makan sehari-hari berbasis home science process skill.

\section{KAJIAN PUSTAKA}

Sains atau Ilmu Pengetahuan Alam merupakan ilmu yang sangat dekat dengan kehidupan manusia. Berdasarkan Lederman, Lederman \& Antink (2013) dalam penelitiannya tentang pencapaian pengetahuan melalui literasi sains dinyatakan bahwa:

"The nature of scientific knowledge is often phrased as "nature of science" and one's perceptions of how scientific knowledge is developed are specifically related to scientific inquiry. These epistemological constructs color the lenses through which individuals' view science, its implications and their lives in the context of science knowledge and practice. The values and beliefs that shape groups of individuals' frames of reference for making sense of the world constitute a worldview"

Penjelasan di atas sekaligus memperkuat pernyataan bahwa pengetahuan atau pemahaman tentang sains dapat diperoleh melalui pengalaman langsung yang telah berulang-ulang dialami atau dilakukan. Pengalaman tersebut akan membuat seseorang belajar tentang pola-pola spesifik yang ada dalam sains . pola yang dimaksud adalah metode ilmiah yang terdiri dari: menemukan masalah, memunculkan hipotesis, melakukan percobaan atau pengujian, menyusun data hasil pegujian serta menyimpulkan. Pembelajaran yang sistematis inilah yang membawa pemahaman sains yang matang akibat proses berpikir, berperilaku dan bersikap secara ilmiah (Widiantono \& Harjono, 2017).

Pendekatan HSPS ini merupakan modifikasi dari pembelajaran Inquiry. Pembelajaran berbasis inquiry merupakan salah satu cara untuk dapat memaksimalkan pemahaman sains peserta didik. Dalam konsep pembelajaran sains modern, diperlukan sebuah cara untuk dapat mendekatkan 
keilmuan alam yang bersifat kaku ke dalam pola pikir masyarakat awam yang dinamis. Cara ini menjadi sangat penting karena pengalaman yang dialami secara pribadi oleh peserta didik akan lebih berdampak signifikan dalam membentuk pengetahuan (Voronov, Grechneva \& Gerashchenko, 2013).

HSPS merupakan pembelajaran berbasis pengalaman mandiri peserta didik yang diarahkan pada kegiatan-kegiatan sehari-hari di rumah. Kegiatan ilmiah yang sering dilakukan di rumah sebagai bagaian dari kebiasaan, menjadi modal untuk meningkatkan pemahaman sains. Kejadian yang dialami sendiri oleh peserta didik melalui kegiatan di rumah sangatlah berkesan. Guru bertindak sebagai fasilitator yang dapat membantu siswa untuk: 1) memunculkan pertanyaan, 2) melakukan analisis 3) menemukan sumber bacaan, 4) mengkaitkan kejadian sehari-hari dengan teori hingga 6) menyimpulkan. Karakteristik dari pendekatan HSPS dituangkan dalam singkatan 5C yaitu: cermati, catat, coba, cipta, cerita. Pendekatan ini telah dimunculkan sejak 2011 oleh Suciati dalam bentuk tugas rumah pembelajaran Biologi. Dalam penelitiannya, Suciati (2011) menyatakan bahwa hasil penugasan yang dikaitkan dengan kegiatan yang sesungguhnya di rumah, menjadi lebih bermakna. Penelitian ini kemudian dilanjutkan oleh Airlanda (2016) yang mengembangkan modul berbasis HSPS untuk meningkatkan keterampilan proses sains. Dari penelitian tersebut, diketahui bahwa keterampilan peserta didik khususnya dalam praktikum menjadi lebih baik jika pokok bahasan IPA dikaitkan dengan kegiatan sehari-hari yang nyata.

\section{METODE PENELITIAN}

Penelitian ini dilakukan pada mahasiswa program studi Pendidikan Guru Sekolah Dasar Universitas Kristen Satya Wacana yang mengambil mata kuliah Konsep Dasar IPA SD tahun pertama. Kelas RS16A bertindak sebagai sampel. Pendekatan yang digunakan adalah home science process skill yang identifikasinya dilakukan selama satu bulan ketika mahasiswa masuk tahun pertama. Jenis penelititian yang digunakan adalah survey dengan mencari fakta yang detail tentang tingkat pemahaman sains mahasiswa PGSD UKSW terkait pola makan sehari-hari. Jenis penelitian ini akan memperkuat identifikasi masalah sehingga dapat memberikan justifikasi tentang tingkat pemahaman sains. Teknik pengumpulan data yang digunakan adalah triagulasi data melalui: angket, wawancara dan observasi. Teknik analisis data yang digunakan adalah deskriptif dengan mengemukakan fakta-fakta yang diperoleh dan ditambahkan kajian teori dalam suatu paragraf.

\section{HASIL PENELITIAN DAN PEMBAHASAN}

Penelitian ini membantu pengajar (dosen) untuk menemukan permasalahan spesifik yang dihadapi mahasiswa PGSD UKSW. Identifikasi mendalam sangat diperlukan agar dosen tidak serta merta menerapkan berbagai macam model pembelajaran di kelas tanpa mengetahui inti permasalahan spesifik yang sedang dihadapi mahasiswa. Seorang pengajar hendaknya mampu memilih dan mengidentifikasi model pembelajaran efektif, menarik dan sesuai dengan peserta didik. Pilihan model yang tepat akan meningkatkan minat serta kinerja peserta didik (Kizlik, 2016). Pernyataan Adom, Agyemang \& Adam (2016) yang juga mempertegas pendapat di atas adalah:

"Learners in a class or level of education usually have distinct characteristics and as such before a particular teaching strategy or teaching method is adopted for a class, the teacher must seriously weigh its impact on the learners. Strategies and methods of teaching exert great influence on students and it may assist or impede their learning outcomes."

Dengan demikian, model pembelajaran tidak muncul hanya karena kehendak pengajar yang memiliki anggapan positif terhadap model tertentu saja. Kesesuaian dengan karakter peserta didik (mahasiswa) justru memiliki dampak yang sangat besar. Melalui survey awal, telah ditemukan data tentang anggapan terkait pemahaman sains mahasiswa PGSD khususnya dalam hal pola makan sehari-hari. Pernyataan ini sesuai dengan salah satu hasil penelitian yang menyatakan: "Avoid concern: lack of concern with experimental findings. The example: careful observation would yield to correct information from student (Risch, 2014)."

Komponen pembelajaran yang baik dan efektif adalah menghindari kekhawatiran kesalahan terjadi dari siswa, namun justru menggali informasi yang paling dimengerti oleh siswa. 
Solusi yang diberikan melalui pendekatan Home science process skill (HSPS) dengan tahapan yang merepresentasikan keterampilan ilmiah dengan istilah 5C, yaitu: cermati, catat, coba, cipta, cerita (Airlanda, 2016). HSPS merupakan pendekatan pembelajaran berbasis sains dengan kasus kehidupan sehari-hari yang juga sering terjadi di rumah. Seorang anak melakukan banyak kegiatan bersifat ilmiah di rumah seperti saat mereka berbicara, memasukkan sendok yang penuh makanan ke mulut, menyiram tanaman, menggosok punggung saat mandi dan lain-lain. Kegiatan ini dapat dibagun sebagai sebuah pembelajaran berbasis sains melalui pendampingan, eksplorasi serta investigasi yang tepat (Department of Education Australia, 2017). Melalui tahapan-tahapan ini, dengan mudah diketahui tingkat kesulitan tertinggi yang dihadapi mahasiswa dalam memahami sains khususnya aplikasi pola makan sehari-hari. Pemilihan topik pola makan sehari-hari dirasa sangat tepat mengingat perbedaan latar belakang sekolah menengah dari mahasiswa PGSD. Jika topik yang dipilih merupakan materi sains level tinggi, dapat dipastikan muncul ketidakpahaman mahasiswa terhadap pembahasan materi dan justru akan mempersulit identifikasi yang akan dilakukan.

Pendekatan ini merupakan hasil modifikasi keterampilan proses sains yang telah ada sebelumnya dan disesuaikan dengan konteks kehidupan di rumah. Keterampilan proses dapat berkembang pada diri seseorang jika mendapatkan kesempatan untuk berlatih. Dengan keterampilan proses, maka seseorang dapat mempelajari sains sesuai dengan keinginannya. Menurut Gagne dalam Dahar (1985) keterampilan proses sains adalah kemampuan-kemampuan dasar tertentu yang dibutuhkan untuk menggunakan dan memahami fenomena dan fakta alam. Setiap keterampilan proses merupakan keterampilan intelektual yang khas, digunakan oleh ilmuwan, serta dapat diterapkan dalam kasus kontekstual (kehidupan sehari-hari). Hasil penelitian Rauf, Othman, Mansor \& Lyndon (2013) membuktikan bahwa sangat diperlukan berbagai pendekatan untuk mampu melaksanakan pembelajaran sains yang efektif. Keterampilan proses sains yang terus ditingkatkan kualitasnya akan membantu peserta didik mencapai level tertinggi dari sebuah tujuan pendidikan berbasis sains (making predictions).

Dasar keilmuan tersebut yang menguatkan pendekatan home science process skill sebagai cara memecahkan masalah identifikasi pemahaman sains mahasiswa melalui pola makan. Berdasarkan sebuah kesimpulan penelitian terdahulu, diketaui bahwa pembelajaran sains hendaknya dilaksanakan secara inkuiri ilmiah (scientific inquiry) untuk menumbuhkan kemampuan berpikir, bekerja dan bersikap ilmiah serta mengkomunikasikannya sebagai aspek penting kecakapan hidup dengan menekankan pada pemberian pengalaman belajar secara langsung melalui penggunaan dan pengembangan keterampilan proses (Kurniawan, 2016). Rincian kegiatan 5C dalam HSPS dapat dilihat pada tabel di bawah ini:

Tabel 1. Rincian Kegiatan dalam Home Science Process Skill (HSPS)

\begin{tabular}{cl}
\hline Tahapan HSPS & \multicolumn{1}{c}{ Keterangan } \\
\hline & a. Mahasiswa dibiasakan untuk mengamati proses ilmiah yang berkaitan dengan pola \\
& makan sehari-hari. \\
Cermati & b. Mahasiswa dibiasakan untuk memikirkan cara kerja organ tubuh yang berkaitan \\
& dengan pencernaan makanan. \\
& c. Mahasiswa dibiasakan untuk mengetahui dengan benar jenis makanan yang \\
& dikonsumsi setiap hari. \\
& d. Mahasiswa dibiasakan untuk memperhatikan dengan seksama bentuk, warna dan \\
& rasa makanan yang dikonsumsi setiap hari. \\
\hline Catat & a. Mahasiswa dibiasakan untuk mencatat jenis dan jumlah makanan yang dibeli dan \\
& dikonsumsi setiap hari. \\
& b. Mahasiswa dibiasakan untuk mencatat cara makanan tersebut diolah. \\
\hline a. Mahasiswa dibiasakan untuk mengelompokkan makanan yang dikonsumsi setiap \\
hari (berdasarkan jenis dan kualitasnya). \\
b. Mahasiswa dibiasakan untuk mencari bahan bacaan terkait makanan sehat. \\
c. Mahasiswa dibiasakan untuk berdiskusi dengan rekannya untuk sharing \\
pengetahuan makanan sehat. \\
d. Mahasiswa diminta mencoba untuk mengolah sendiri makanan yang akan \\
dikonsumsi.
\end{tabular}


a. Mahasiswa diminta mencoba untuk membuat menu makanan sehat.

b. Mahasiswa diminta mencoba untuk membuat jadwal pola makan sehari-hari.

c. Mahasiswa diminta mencoba menghitung kebutuhan izi dalam setiap konsumsinya.

Cipta d. Mahasiswa diminta mencoba merencanakan kebutuhan persediaan makanan bulanan.

e. Mahasiswa diminta untuk memperkirakan dampak yang ditimbulkan ketika mengkonsumsi suatu makanan dalam jangka waktu yang lama.

f. Mahasiswa diminta untuk mencoba membuat perencanaan pengeluaran dana untuk konsumsi.

a. Mahasiswa diminta untuk menyampaikan hasil identifikasi yang mereka lakukan di kelas.

Cerita b. Mahasiswa diminta untuk membuat produk ilmiah berupa rangkuman kegiatan yang telah mereka lakukan.

c. Mahasiswa diminta untuk memprediksi kesulitan yang selama ini dihadapi dalam memahami sains dalam pola makan sehari-hari.

Data yang diperoleh dari identifikasi angket tentang tingkat pemahaman sains melalui tahapan HSPS dapat dilihat pada gambar 1 di bawah ini:

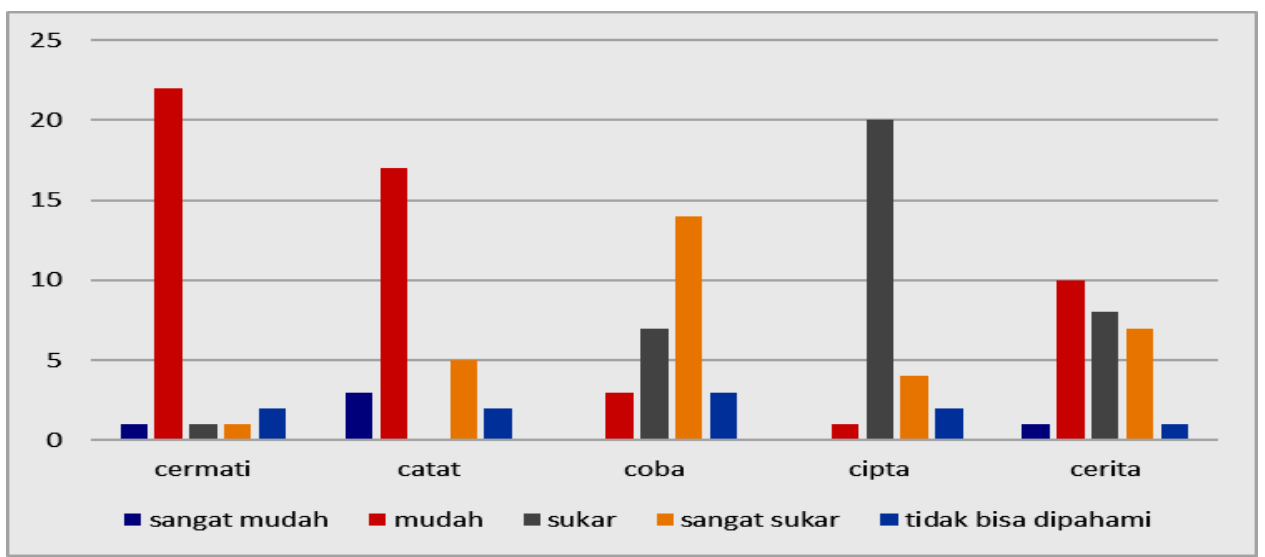

Gambar 1. Diagram Perbandingan Tingkat Pemahaman Sains Tentang Pola Makan Mahasiswa Berbasis Tahapan Home Science Process Skill

Data tersebut menunjukkan bahwa mahasiswa tidak mengalami kesulitan yang cukup berarti pada tahapan "cermati dan catat". Pada tahapan ini mahasiswa diajak untuk mencermati dan mencatat perilaku makan yang dilakukan sehari-hari, seperti: frekuensi makan dalam satu hari, jenis makanan dalam satu hari, warna makanan yang tersaji, cara memasak makanan yang akan dimakan. Namun, terdapat 7,4\% mahasiswa yang justru tidak bisa mencermati dan mencatat pola makan dirinya sendiri. Setelah dilakukan identifikasi melalui wawancara, diketahui bahwa mahasiswa tersebut memiliki pola makan yang buruk. Mereka tidak memiliki waktu yang pasti ketika makan, terkadang makan dalam jumlah banyak tapi terkadang tidak makan karena tidak memiliki uang yang cukup. Perilaku seperti ini menjadikan mereka tidak dapat mencermati dan mencatat pola makannya sendiri.

Hasil yang berbeda ditunjukkan pada saat tahapan "coba", sekitar 51,85\% mahasiswa tercatat dalam kategori sangat sukar. Pada tahapan ini, mereka diminta untuk melakukan beberapa hal seperti: mengelompokkan jenis makanan, mencari bahan bacaan tentang pola makan, melakukan konsultasi dengan ahli gizi, melakukan diskusi dengan teman tentang makan makanan sehat, serta menjawab pertanyaan melalui survey online (google form). Berdasarkan hasil kajian yang mendalam, mahasiswa mengalami kesulitan ketika membandingkan pola makan yang telah dilakukan pada tahap "cermati dan catat" dengan teori yang mereka cari pada tahap "coba". Kesulitan ini terjadi karena mahasiswa mengandalkan searching internet (google.com) dalam mencari sumber. Pengetahuan yang rendah tentang jurnal dengan topik pola makan sehari-hari, menjadikan tahapan ini sangat sukar. Mahasiswa sering mengalami kebingungan ketika mendapatkan sumber yang memiliki kesimpulan berbeda.

Pada tahapan HSPS "cipta", terdapat 74,07\% mahasiswa menganggap sukar. Kesulitan ini dihadapi ketika mereka diminta untuk mulai membuat atau menciptakan beberapa hal seperti: jadwal 
menu makanan sehat, perhitungan jumlah kebutuhan makanan dalam satu hari, dan alternatif persediaan makanan dalam satu bulan. Penyebab utamanya adalah mahasiswa belum pernah membuat jadwal dan perhitungan kebutuhan makanan sehari-hari, sehingga mereka harus berusaha keras mempelajari buku serta kaitannya secara nyata di lapangan. Alasan kedua mahasiswa mengalami kesulitan adalah perencanaan yang dibuat dianggap tidak sesuai dengan kenyataan, karena penyediaan kebutuhan menu makanan sehat akan membuat mereka mengeluarkan dana dua kali lipat lebih banyak dibanding pola makan yang biasa mereka lakukan.

Selain itu, pada tahapan "cerita" home science process skill diperoleh sebesar 37,03\% menganggap mudah, 29,62\% menganggap sukar dan 25,92\% menganggap sangat sukar. Pada tahapan ini, mahasiswa diminta untuk menceritakan pengalaman mereka dalam mengidentifikasi pola makan sehari hari serta menceritakan pendapat mereka terkait kasus-kasus yang berhubungan dengan makanan sehari-hari. Setalah dilakukan identifikasi medalam dengan wawancara, ditemukan sebesar 55,55\% mahasiswa menuliskan sukar dan sangat sukar. Keadaan ini terjadi karena mereka tidak bisa mengkaitkan hasil yang telah diperoleh dari tahapan-tahapan sebelumnya (cermati, catat, coba, cipta). Pemahaman yang rendah mengakibatkan mahasiswa belum bisa menarik benang merah antara kegiatan satu dengan yang lain. Mereka mengerjakan hanya sesuai dengan petunjuk yang diberikan tanpa bisa mengetahui hubungan antar kegiatan.

Indikator HSPS yang lain menunjukkan bahwa 51,85\% mahasiswa jarang memikirkan bahwa organ tubuhnya sedang melakukan proses pencernaan yang terjadi dalam beberapa mekanisme. Persentase yang sama $(51,85 \%)$ juga terjadi pada hasil angket yang menyatakan bahwa mahasiswa jarang mempedulikan cara memasak makanan yang mereka makan. Sebesar 66,66\% mahasiswa tidak pernah meluangkan waktu mereka untuk membuat jadwal makan makanan sehat. Data tersebut tenyata terkait erat dengan $48,14 \%$ mahasiswa yang menyatakan bahwa mereka tidak mengerti tentang cara mencari referensi makanan sehat. Berbanding lurus dengan data 74,07\% mahasiswa yang sangat memperhitungkan jumlah pengeluaran dana untuk makan dalam 1 minggu. Namun, diperolah data yang sangat berlawanan bahwa sebesar $85,18 \%$ mahasiswa menyatakan bahwa mereka peduli tentang kesehatan pencernaannya. Dari analisis data observasi di atas, diketahui bahwa motivasi mahasiswa dalam menjaga kesehatan pencernaan tidak dimbangi dengan pemahaman yang tepat. Mahasiswa cenderung mengacuhkan hal detail yang justru merupakan bagian yang sangat sesuai dengan konsep sains dalam kehidupan sehari-hari khususnya dalam hal pencernaan.

Hasil identifikasi di atas sesuai dengan teori yang menyatakan bahwa produk sains yang berkualitas dapat diperoleh dari tahapan ilmiah yang jelas dan lengkap (Lu'lu, 2016). Tahapan ilmiah yang jelas dan lengkap telah disediakan melalui 5C tahapan home science process skill, namun hasil yang diperoleh belum maksimal. Pernyataan tersebut sejalan dengan hasil penelitian Putra (2016) yang memberikan kesimpulan bahwa keterampilan proses sains berpengaruh positif terhadap pemahaman konsep IPA. Dapat diidentifikasi melalui data di atas bahwa ketika keterampilan proses sains masih dalam kategori "sukar dan sangat sukar" bahkan "tidak bisa dipahami" oleh mahasiswa PGSD UKSW, maka pemahaman sains juga masih rendah.

Penelitian ini menunjukkan bahwa kesulitan tertinggi terjadi ketika mahasiswa diminta untuk mencoba dan menciptakan sesuatu yang berkaitan dengan sains. Fakta ini perlu mendapatkan perhatian karena justru kualitas pemahaman sains yang baik didukung oleh kegiatan mencoba dan menciptakan yang baik juga. Kedua kegiatan tersebut biasanya dikemas dalam bentuk praktikum. Sesuai dengan teori yang menyatakan bahwa kegiatan praktikum atau berlaboratorium akan memberi peran yang sangat besar terutama dalam membangun pemahaman konsep, verifikasi (pembuktian) kebenaran konsep, menumbuhkan keterampilan proses (keterampilan dasar bekerja ilmiah dan kemampuan afektif), dan menumbuhkan "rasa suka" terhadap pelajaran IPA (Koretsky, dkk.,2011). Teori Mc Geoch (1956) dalam Maknun (2012) memberikan definisi belajar "learning is a change perforfermance as a result of practice". Pernyataan tersebut berarti bahwa belajar membawa perubahan dalam kinerja yang disebabkan oleh proses latihan. Dalam hal ini jelaslah bahwa penguasaan keterampilan-keterampilan esensial dapat terkuasai dengan baik jika melakukan praktek nyata untuk mendapatkan pengalaman belajar. Kualitas pembelajaran sains abad 21 ternyata diukur dengan tinggi rendahnya penguasaan keterampilan proses sains dan kemampuan analisis kasus. Guru dan siswa yang secara konsisten melakukan penyelidikan serta pengukuran ilmiah menjadi bukti nyata usaha untuk meningkatkan keterampilan dan kemampuan sains yang dibutuhkan di abad 21 (Irwanto et all, 2017). 
Pemahaman sains yang rendah perlu mendapatkan perhatian untuk dapat ditingkatkan secara perlahan. Menurut Sa'idah (2010), pemahaman konsep adalah pemahaman seseorang terhadap dasar kualitatif di mana fakta-fakta saling berkaitan dengan kemampuannya untuk menggunakan pengetahuan tersebut dalam situasi baru. Pembelajaran sains hadir sesuai dengan hakikat yang juga harus dipahami oleh seorang calon guru sains. Kualitas ketercapaian pembelajaran sains diukur dari tingkat penyelesaian masalah yang telah dilakukan (Isdaryanti et all, 2018). Berbagai cara penyelesaian masalah sebenarnya dapat dicari melalui teknologi yang berkembang sekarang ini. Namun, diperlukan motivasi dan rasa ingin tau (curiosity) yang kuat untuk dapat menghadirkan pembelajaran kualitas tinggi (Viel et all, 2014).

Teori-teori di atas menunjukkan bahwa pemahaman sains yang baik sangat diperlukan calon guru sekolah dasar sebagai bekal mengajar. Apalagi seorang guru SD harus membimbing 5 muatan pembelajaran sekaligus. Hakikat serta tujuan utama dari masing-masing komponen keilmuan hendaknya tidak saling tumpang tindih ataupun saling mendominasi. Selain itu seorang calon guru SD akan mengajar dengan pedoman Kurikulum 2013 yang berbasis tematik. Selaras dengan penelitian Fitriani et all (2016) bahwa :"ideally the thematic learning should be an enjoyable learning process because the thematic learning departs from the students' interests and needs. The learning process have to be more impressive and meaningful." Telah dibahas sebelumnya muara dari kegiatan seharihari berkaitan erat dengan sains dan penyelidikan ilmiah. Membiasakan diri dalam penyelidikan ilmiah pada setiap kegiatan sehari-hari memberi dampak positif terhadap peningkatan pengetahuan, manajemen waktu dan kompleksitasnya (Susilawati et all, 2018). Oleh karena itu diperlukan langkah lanjutan yang perlu dilakukan setelah identifikasi ini. Tindakan yang disarankan untuk menyelesaikan permasalahan di atas adalah melakukan pembiasaan praktikum berbasis permasalahan kontekstual.

\section{SIMPULAN}

Berdasarkan data dan pembahasan, dapat disimpulkan tahapan home science process skill dapat membantu mengidentifikasi secara spesifik tingkat pemahaman sains mahasiswa PGSD UKSW. Data penelitian menunjukkan bahwa pemahaman sains mahasiswa PGSD UKSW masih rendah pada kasus pola makan dalam kehidupan sehari-hari. Melalui pendekatan home science process skill diketahui secara detail bahwa mahasiswa mengalami kesulitan tertinggi pada tahapan "coba dan cipta", sehingga menunjukkan tingkat pemahaman sains yang masih rendah. Tulisan ini merupakan identifikasi awal untuk melakukan penelitian lanjutan berupa action research yang mengarah pada analisis pendekatan home science process skill untuk meningkatkan setiap indikator yang telah dikaji sebelumnya.

\section{DAFTAR PUSTAKA}

Adom, Dickson., Adam, Saeed., Agyemang, Osafo. 2016. Effective Instructional Methods and Strategies for Teaching Art History. International Journal of Art and Art History, 4(2), 45-62.

Airlanda, G.S. 2016. Pengembangan Modul Pembelajaran Biologi Berbasis HSPS Dipadukan Blended Learning untuk Meningkatkan Keterampilan Proses Sains Siswa IPA SMA Kristen Petra Malang. Jurnal Pendidikan Sains Volume 4(1), 1-8.

Asyhari \& Clara. 2017. Pengaruh Pembelajaran Levels of Inquiry Terhadap Kemampuan Literasi Sains Siswa. Jurnal Scientiae Educatia: Jurnal Pendidikan Sains, Vol 6 (2), 87-101.

Atmojo, S.E. 2012. Profil Keterampilan Proses Sains dan Apresiasi Siswa Terhadap Pengrajin Tempe dalam Pembelajaran IPA Berpendekatan Etnosains. Jurnal Pendidikan IPA Indonesia, 1(2), 115-122.

Dahar, R.W., 1985. Kesiapan Guru Mengajarkan Sains di Sekolah Dasar ditinjau dari Segi Pengembangan Keterampilan Proses Sains (Suatu Iluminatif tentang Proses Belajar Mengajar Sains di Kelas 4, 5 dan 6 Sekolah Dasar). Disertasi Doktor. Bandung: FPS IKIP Bandung. Tidak diterbitkan. 
Department of Education Australia. 2017. Exploring Science Technology, Engineering and Mathematic at Home. Government of Western Australia, Public Education A World of Opportunities. SCIS NO: 1831078.

Dimyati, M. 2006. Belajar dan Pembelajaran. Jakarta: Departemen Pendidikan dan Kebudayaan.

Faulkner \& Latham. (2016). Adventurous Lives: Teacher Qualities for 21st Century Learning. Australian Journal of Teacher Education, Vol 41 (4), 136-150.

Fitriani, Andhin., Mulyasari, Effy., Prabawa., Kamia. 2016. Developing Thematic Teaching Materials: Their Implementation in Project-Based Learning at Elementary Level. International Journal of Control Theory and Applications, 9 (35).

Franco, Lara., Shanahan, Danielle., Fuller, Richard. 2017. A Review of the Benefits of Nature Experiences: More Than Meets the Eye. Journal of Environtmental Research and Public Health, Vol 14 (846), 1-29.

Irwanto., Rohaeti, Eli., Widjajanti, Endang., Suyanta. 2017. Students' Science Process Skill and Analytical Thinking Ability in Chemistry Learning. The 4th International Conference on Research, Implementation, and Education of Mathematics and Science (4th ICRIEMS).

Isdaryanti, B., Rachman, M., Sukestiyarno., Florentinus, T., Widodo. (2018). Teachers' Performance in Science Learning Management Integrated with Character Education. Jurnal Pendidikan IPA Indonesia, JPII 7 (1), 9-15.

Istijabatun, S. 2013. Pengaruh Pengetahuan Alam Terhadap Pemahaman Mata Pelajaran Kimia. Jurnal Inovasi Pendidikan Kimia, Volume 2 No.2 halaman 323-329.

Kizlik, B. 2016. Instructional Methods Information (Part 1). Robert Kizlik \& Associates, Florida: Boca Raton. (online) (http://www.adprima.com/teachmeth.htm.) diakses 1 Oktober 2018.

Koretsky, M. D., Christine, K., \& Gummer, E. 2011. Student Perceptions of Learning in the Laboratory: Comparison of Industrially Situated Virtual Laboratories to Capstone Physical Laboratories. Journal of Engineering Education, 100(3), 540-573.

Kurniawan, A. 2016. Profil Penguasaan Keterampilan Proses Sains Mahasiswa Program Pendidikan Guru Sekolah Dasar Universitas Terbuka. Prosiding Seminar Nasional Biologi, Sains dan Lingkungannya, 13(1), 410-419.

Lederman, N.G, Lederman, J.S \& Antink, A. 2013. Nature of Science and Scientific Inquiry as Context for the Learning of Science and Achievement of Scientific Literacy. International Journal of Education in Mathematics, Science and Technology (IJEMST), 1(3), 138-147.

Lu'Lu, S. 2016. Improving Students Science Process Skills on Biology using Bounded Inquiry Lab Model. Jurnal Bioedukasi, 9(2), 49-54.

Maknun, D., Surtikanti, H. 2012. Keterampilan Esenssial dan Kompetensi Motorik Laboratorium Mahasiswa Calon Guru Biologi dalam Kegiatan Praktikum Biologi. Jurnal Pendidikan IPA Indonesia, 1(2), 141-148.

Permendiknas Nomor 16 Tahun 2007. Standar Kualifikasi Akademik dan Kompetensi Guru. Kementerian Pendidikan dan Kebudayaan. (online), (http://vervalsp.data.kemdikbud.go.id/ prosespembelajaran/file/Permendiknas\%20No\%2016\%20Tahun\%202007.pdf). (online). Diakses 6 Januari 2018.

Rauf, Abd Rose., Rasul, Sattar.,Mansor, Azlin., Othman., Lydon. 2013. Inculcation of Science Process Skills in a Science Classroom. Canadian Center of Science and Education. Journal of Asian Social Science, 9(8), 46-57.

Risch, M. 2014. Investigation about representations used in teaching to prevent misconceptions regarding inverse proportionality. Journal of STEM Education, 1(4), 2-7.

Rustaman, N. 2011. Pendidikan dan Penelitian Sains dalam Mengembangkan Keterampilan Berpikir Tingkat Tinggi untuk Pembangunan Karakter. Prosiding Seminar Nasional Biologi, 8(1). 
Identifikasi Pemahaman Sains Mahasiswa PGSD UKSW Tentang Pola Makan Sehari-Hari Berbasis

Home Science Process Skill (Gamaliel Septian Airlanda)

Sa'idah, N. 2010. Peningkatan Pemahaman Konsep-konsep IPA melalui Pendekatan Contextual Teaching and Learning pada Siswa Kelas V SD Negeri Sondakan No 11 Surakarta Tahun pelajaran 2009/2010. Universitas Sebelas Maret: Surakarta.

Suciati. 2011. Tugas Rumah Berbasis Home Science Process Skill (HSPS) pada Pembelajaran Biologi untuk Mengembangkan Literasi Sains Siswa. Prosiding Seminar Nasional VIII Pendidikan Biologi, 8(1), 253-260.

Susilawati., Wijayanto., Khoiri, N., Masturi., Xaphakdy. 2018. LEARNING EXPERIENCE OF PRESERVICE PHYSICS TEACHERS IN DEVELOPING SIMPLE PROJECT LOADED BY LIFE SKILLS. Jurnal Pendidikan IPA Indonesia, JPII 7(1), 122-129.

UNESCO. 2015. Quality Science Education and 21st-Century Skills. http://webarchive.unesco.org/20160930040522/ (online). Diakses pada tanggal 9 Desember 2017.

Viel, C., Rodrigues., Melo, E., Bueno., Pimentel, M. 2014. Interaction with a Problem Solving Multi Video Lecture: Observing Students from Distance and Traditional Learning Courses. International Journal of Emerging Technologies in Learning, 9(1), 39-46.

Voronov, V.K., Grechneva, M.V \& Gerashchenko, L.A. 2013. The Program of Lecture Course "Consepts of Modern Natural Sciences. American Journal of Educational Research, 1(8), 344-349.

Widiantono, Nugroho \& Harjono, Nyoto. 2017. Penerapan Model Pembelajaran Interaktif untuk Meningkatkan Aktivitas dan Hasil Belajar IPA Siswa Kelas 5 SD. Scolaria: Jurnal Pendidikan dan Kebudayaan, 7(3), 199-213. 